\title{
IMMUNOCHEMICAL ASSAY OF CHLORAMPHENICOL IN HONEY
}

\author{
IONELA DANIELA MORARIU, LILIANA AVASILCĂI, MĂDĂLINA VIERIU, OANA CIOANCĂ *, \\ MONICA HĂNCIANU
}

“Grigore T. Popa” University of Medicine and Pharmacy, Faculty of Pharmacy, 16 Universitătii Street, 700115, Iaşi, Romania

*corresponding author: oana.cioanca@umfiasi.ro

Manuscript received: April 2018

\begin{abstract}
The veterinary use of chloramphenicol in food-producing animals is forbidden in the European Union. As it is still used for the treatment of infections in animals not bred for consumption, traces of the drug may be found in honey. Developing accessible methods to detect traces of chloramphenicol is of high interest to food residue monitoring and regulation programs. We propose an immunochemical method as an alternative to detect chloramphenicol in honey using Biochip Technology. The sensitivity of the new quantitative determination method for chloramphenicol was high (IC50 $=0.74$ $\mu \mathrm{g} / \mathrm{kg}$ ). The method presented very good accuracy both within the same analytical series and in different analytical series with typical values lower than $15 \%$ for concentration levels of $0.5,1$ and $1.5 \mu \mathrm{g} / \mathrm{kg}$. The decision limit $(\mathrm{CC} \alpha)$ of chloramphenicol was $0.37 \mu \mathrm{g} / \mathrm{kg}$, while the detection capability $(\mathrm{CC} \beta)$ was $0.42 \mu \mathrm{g} / \mathrm{kg}$. The method was applied to the determination of chloramphenicol residues in Romanian honey samples.
\end{abstract}

\section{Rezumat}

Utilizarea cloramfenicolului în medicina veterinară la animalele crescute pentru consum este interzisă în Uniunea Europeană. Se găsesc însă urme de substanţă medicamentoasă în miere, deoarece este folosită pentru tratamentul infecţiilor la animalele care nu sunt crescute pentru consum. Dezvoltarea unei metode accesibile pentru detecţia urmelor de cloramfenicol este de mare interes pentru programele de monitorizare şi control a reziduurilor din alimente. Propunem o metodă imunochimică folosind tehnologia Biochip ca o alternativă pentru analiza cloramfenicolului în miere. Sensibilitatea noii metode de determinare cantitativă a cloramfenicolului este mare (IC50 =0,74 $\mu \mathrm{g} / \mathrm{kg}$ ). Metoda prezintă o precizie foarte bună atât în cadrul aceleiaşi serii analitice, cât şi în serii analitice diferite, cu valori mai mici de $15 \%$ pentru nivelurile de concentraţie de $0,5,1$ şi $1,5 \mu \mathrm{g} / \mathrm{kg}$. Limita de detecţie $(\mathrm{CC} \alpha)$ a fost $0,37 \mu \mathrm{g}$ cloramfenicol $/ \mathrm{kg}$, în timp ce capacitatea de detecţie (CC $\beta)$ a fost $0,42 \mu \mathrm{g} / \mathrm{kg}$. Metoda a fost aplicată pentru determinarea reziduurilor de cloramfenicol în probe de miere din România.

Keywords: chloramphenicol, honey, Biochip

\section{Introduction}

Honey from across the world is contaminated with potent pesticides $[8,10,14,15]$. When analysed almost half the samples contained a cocktail of pesticides [1, 5, 6, 9, 17-22, 24-26].

Chloramphenicol is an aminoglycoside obtained for the first time in 1947 from Streptomyces venezuela $[3,7]$, but since 1950 it is obtained through synthesis. Chloramphenicol has bacteriostatic activity and it is effective in treating infectious diseases [23]. The mechanism of action of chloramphenicol is based on the inhibition of the transport of activated amino acids to the site of protein synthesis (ribosomes), i.e. inhibiting the synthesis of bacterial proteins. Resistance installs very slowly and it is due to the development of enzymes that break down chloramphenicol such as hydrolases, reductases or acetyltransferases [7].

Because of the side effects that chloramphenicol has on human health, its use in veterinary medicine has been banned by the FDA in the US, by the Canadian Health Protection Branch and by the
European Union in those animals whose products and by-products are used for human consumption. However, chloramphenicol has been shown to be one of the most commonly found drug residues found in honey [1-2, 5, 11-13, 27, 29-34].

The present study aimed to achieve validation of a quantitative determination method for chloramphenicol, using Biochip technology and to validate the new method for the determination of chloramphenicol residues in Romanian honey samples.

\section{Materials and Methods}

All reagents were supplied in a compact kit that included Antimicrobial Array III - kit EV3695 and Antimicrobial Array III Control - kit AMC5036, produced by Randox Laboratories, UK.

The validation method and the honey analysis procedure were performed in accordance with 2002/657/EC Decision, FDA approved validation guidelines and validation guidelines for screening methods for veterinary drug residues. The validation parameters evaluated were: linearity, 
FARMACIA, 2019, Vol. 67, 2

sensitivity (IC50), specificity and selectivity, precision (intermediate and reproducibility), accuracy, detection limit and recovery $[17,18,20]$. The linearity of the method was evaluated by performing a 9-point calibration using the calibrators included in the Anti Microbial Array III kit. Considering the complex honey composition as a sample matrix, the linearity of the method was also checked by spiking blank honey samples in order to obtain nine concentration levels: $0,0.001,0.01$, $0.05,0.1,1,4,10$ and $50 \mu \mathrm{g}$ chloramphenicol $/ \mathrm{kg}$.

The analysis software used a specific calibration equation $[4,16]$ :

$$
\mathrm{y}=\mathrm{D}+\left[(\mathrm{A}-\mathrm{D}) / 1+(\mathrm{x} / \mathrm{C})^{\mathrm{B}}\right], \text { where: }
$$

$\mathrm{x}=$ analyte concentration $(\mu \mathrm{g} / \mathrm{kg}) ; \mathrm{y}=$ the intensity of the chemiluminescent signal expressed as relative light units (RLU); A, B, C, D = parameters of the competitive method, predefined in the analyser software as $\mathrm{A}=$ the intensity of the chemiluminescent signal of the blank, $\mathrm{B}=$ slope factor, $\mathrm{C}=$ the inflection point of the calibration curve and $\mathrm{D}=$ the intensity of the luminous response signal at an infinite theoretical concentration of the analyte [17].

An initial estimate was made for each parameter, and then it was optimized by minimizing the sum of the squares of the residuals using Microsoft Excel Solver.

The procedure used in order to obtain the calibration curves included the following steps: adding $50 \mu \mathrm{L}$ of each calibrator to the surface of each Biochip followed by the addition of $150 \mu \mathrm{L}$ of reaction buffer (AM III DIL ASY); incubating the Biochips at $25^{\circ} \mathrm{C}$ while stirring at $370 \mathrm{rpm}$ for 30 minutes; adding $100 \mu \mathrm{L}$ of enzyme conjugate solution to each Biochip; incubating for 30 minutes the Biochips at $25^{\circ} \mathrm{C}$ while stirring at $370 \mathrm{rpm}$; removing the reaction mixture by washing the reaction surface 6 times, in order to remove the components that did not bind to the polyclonal antibodies present on the solid substrate on surface of the Biochip; after complete removal of the reaction mixture, $250 \mu \mathrm{L}$ of reagent (luminol: peroxide $1: 1 \mathrm{v} / \mathrm{v}$ ) had been added; the Biochips were left to rest in the dark for the development of the reaction and exactly 2 minutes after, they were placed in the image capture chamber for processing and interpretation of the signal.

The sensitivity of the method expressed as the Inhibitory Concentration (IC50) was calculated based on $50 \%$ of the value of the RLU signal generated by the zero-concentration calibrator and extrapolating the RLU value thus obtained on the $\mathrm{X}$-axis of the calibration curve where the concentration units were expressed as $\mu \mathrm{g} / \mathrm{kg}$. The concentration thus obtained corresponded to the inhibitory concentration that produced $50 \%$ inhibition [18].

The specificity and selectivity of the method were analysed by adding the analyte separately in known concentrations of (10 and $100 \mu \mathrm{g} / \mathrm{kg}$ ) to the zeroconcentration calibrator in serial dilutions. To assign the cross-reactivity percentage, three replicates were assessed for each analyte level in the serial dilution.

Cross-reactivity was calculated using the formula:

$$
\% \mathrm{CR}=\left[\mathrm{IC} 50_{\text {analyte }} / \mathrm{IC} 50_{\text {cross-reactant }}\right] \times 100 .
$$

Antimicrobial Array III Control - code AMC5036, manufactured by Randox Laboratories, UK, was used to evaluate the accuracy and precision. Mean concentration, standard deviation, and coefficient of variation $(\% \mathrm{CV})$ were also calculated.

Because the residues of chloramphenicol have a 1 $\mu \mathrm{g} / \mathrm{kg}$ reference point for action, that was the reason the target concentration for screening was set at 0.5 $\mu \mathrm{g} / \mathrm{kg}$ ( $50 \%$ of reference point for action).

According to current legislation and validation guidelines for methods of drug determination in honey, precision and accuracy must be assessed for the minimum required performance limit (MRPL) which was $1 \mu \mathrm{g} / \mathrm{kg}$, and then for $50 \%$ and $150 \%$ MRPL.

The precision in the same analytical series was determined by analysing 20 replicates of negative honey samples, spiked in order to obtain 3 different concentration levels: $0.5,1$ and $1.5 \mu \mathrm{g} / \mathrm{kg}$.

The precision in different analytical series was determined by analysing two replicates of blank honey samples spiked with chloramphenicol at three different concentration levels $(0.5,1$ and 1.5 $\mu \mathrm{g} / \mathrm{kg}$ ) in 10 different days of analysis.

Precision and accuracy are acceptable if the coefficient of variation in the concentration of the control samples measured does not exceed $\pm 15 \%$ for determinations on the same day or on different days or analytical series.

In order to determine the decision limit $(\mathrm{CC} \alpha)$ and the detection capability (CC $\beta) 20$ blank honey samples were selected and spiked at the target concentration for screening - $0.5 \mu \mathrm{g} / \mathrm{kg}$. $\mathrm{CC} \alpha$ was calculated as the arithmetic mean of the concentration in 20 spiked samples. The concentration level of each analyte was MRPL plus $1.64 \times$ standard deviation of repeatability at $\alpha=5 \%$. CC $\beta$ was calculated as the arithmetic mean of the concentration analyte at $\mathrm{CC} \alpha$ plus $1.64 \times$ standard deviation of repeatability at $\alpha=5 \%$.

The recovery percentage was calculated for three chloramphenicol concentration levels $0.5,1,1.5$ $\mu \mathrm{g} / \mathrm{kg}$ in spiked honey samples. Recovery percentages were calculated by plotting the ratio of the analyte concentration in the sample against the theoretical concentration of the analyte in the standard 
solution. According to the validation guidelines, the requirement for the recovery percentage for the determination of drug residues in honey must be higher than $70 \%$.

The validated method was used for the analysis of Romanian honey samples purchased from supermarkets or from private producers. The samples had been stored at room temperature and in the dark.

Sample processing included derivatization and extraction from honey samples. The procedure included the following steps: $1 \mathrm{~g}$ of honey sample was mixed with $4 \mathrm{~mL}$ distilled water, incubated at $37^{\circ} \mathrm{C}$ for 30 minutes, and stirred 10 minutes until dissolved; $0.5 \mathrm{~mL}$ of $1 \mathrm{M} \mathrm{HCl}$ and $100 \mu \mathrm{L}$ of 10 $\mathrm{mM}$ 4-nitrobenzaldehyde solution were added to the sample solution; the mixture was stirred for 10 minutes, and then incubated for 16-24 hours at $37^{\circ} \mathrm{C}$; after incubation, $5 \mathrm{~mL}$ dipotassium phosphate $0.1 \mathrm{M}$ solution was added to each sample, and the $\mathrm{pH}$ was adjusted to 7.4 with $1 \mathrm{M} \mathrm{NaOH}$ solution; $15 \mathrm{~mL}$ ethyl acetate were added to $5 \mathrm{~mL}$ of derivatized honey sample, which was stirred on a Vortex shaker for 12 minutes; the sample was centrifuged for 10 minutes using 4500 relative centrifugal force; $6 \mathrm{~mL}$ of supernatant from each sample was transferred into microtubes, which were then evaporated at $60^{\circ} \mathrm{C}$ and $15 \mathrm{psi}$; the residue was mixed with $375 \mu \mathrm{L}$ of sample diluent provided in the kit (AM III DIL SPE) and stirred for 2 minutes. Confirmation of the results obtained using the Biochip method for the analysed honey samples was performed by using a validated LC-MS/MS method [15] on an Agilent 1100 LC (Agilent Technologies, USA) coupled with a 4000 Q TRAP mass spectrometer (Applied Biosystems, USA), and the acceptance rules were: signal/noise ratio $>3 \pm$ $2.5 \%$ differentiation of analyte retention time and corresponding standard, $\pm 20 \%$ deviation of the relative abundance of the analyte and $\pm 50 \%$ deviation of the corresponding standard.

\section{Results and Discussion}

The calibration curve (Figure 1) showed a correlation coefficient (r) of 0.991 for the linearity range $0-5 \mu \mathrm{g} / \mathrm{kg}$, thus fulfilling the admittance condition of the calibration curve $(r>0.949)$.

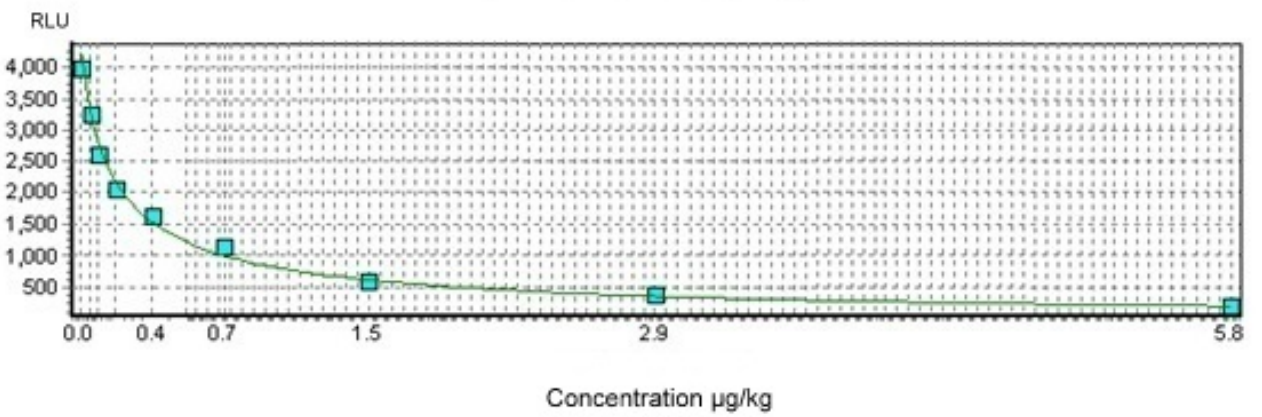

Figure 1.

Calibration curve for chloramphenicol

The sensitivity of the method expressed as IC50 for the simultaneous quantitative determination of chloramphenicol was $0.74 \mu \mathrm{g} / \mathrm{kg}$.

While studying of specificity and selectivity, the cross-reactivity (\%) for chloramphenicol was 100 and for cross-reactant - chloramphenicol glucuronide, it was 17 . According to the validation guides, the cross-reactivity percentage $(\% \mathrm{CR})$ for the determination of drug residues in honey must not exceed $25 \%$ for the analyte concentration at the minimum limit of quantification. The assayed validation parameters are shown in Table I and Table II.

The validated Biochip method was applied to the analysis of 16 samples of honey from various geographic regions in Romania. The results were confirmed using the LC-MS/MS method. The performance of the Biochip method was very good, the values obtained were comparable to the results obtained for both positive samples and negative samples (Table III).

Table I

Precision of the used method

\begin{tabular}{|c|c|c|c|}
\hline Series & Level & $\begin{array}{c}\text { Concentration } \\
(\boldsymbol{\mu g} / \mathbf{k g})\end{array}$ & $\begin{array}{c}\mathbf{C V} \\
\mathbf{( \% )}\end{array}$ \\
\hline \multirow{3}{*}{ Identical } & 1 & 0.32 & 9.06 \\
\cline { 2 - 4 } & 2 & 0.75 & 6.97 \\
\cline { 2 - 4 } & 3 & 1.06 & 7.34 \\
\hline \multirow{3}{*}{ Different } & 1 & 0.44 & 8.92 \\
\cline { 2 - 4 } & 2 & 0.75 & 7.26 \\
\cline { 2 - 4 } & 3 & 1.06 & 9.84 \\
\hline
\end{tabular}


FARMACIA, 2019, Vol. 67, 2

\section{Table II}

Recovery, decision limit and detection capability

\begin{tabular}{|c|c|c|c|}
\hline & Level 1 & Level 2 & Level 3 \\
\hline Concentration $(\mu \mathrm{g} / \mathrm{kg})$ & 0.32 & 0.75 & 1.06 \\
\hline Recovery (\%) & 64 & 75 & 71 \\
\hline $\begin{array}{c}\text { Average concentration } \\
(\mu \mathrm{g} / \mathrm{kg})\end{array}$ & \multicolumn{3}{|c|}{0.32} \\
\hline Standard deviation (SD) & \multicolumn{3}{|c|}{0.03} \\
\hline $1.64 \times$ SD & \multicolumn{3}{|c|}{0.05} \\
\hline $\mathrm{CC} \alpha(\mu \mathrm{g} / \mathrm{kg})$ & \multicolumn{3}{|c|}{0.37} \\
\hline$C C \beta(\mu \mathrm{g} / \mathrm{kg})$ & \multicolumn{3}{|c|}{0.42} \\
\hline
\end{tabular}

Table III

Comparison of the results determined through Biochip and LC-MS/MS methods

\begin{tabular}{|c|c|c|}
\hline Sample No & $\begin{array}{c}\text { Biochip } \\
(\mu \mathrm{g} / \mathrm{kg})\end{array}$ & $\begin{array}{c}\text { LC-MS/MS } \\
(\mu \mathrm{g} / \mathrm{kg})\end{array}$ \\
\hline 1 & 0.79 & 0.88 \\
\hline 2 & 0.84 & 0.33 \\
\hline 3 & 3.07 & 2.34 \\
\hline 4 & 0.23 & 0.07 \\
\hline 5 & 0.76 & 0.61 \\
\hline 6 & 0.49 & 0.29 \\
\hline 7 & 0.77 & 0.43 \\
\hline 8 & 0.44 & 0.94 \\
\hline 9 & 0.11 & 0.32 \\
\hline 10 & 0.11 & 0.32 \\
\hline 11 & 0.11 & 0.32 \\
\hline 12 & 0.85 & 0.12 \\
\hline 13 & 0.44 & 0.14 \\
\hline 14 & 0.11 & 0.02 \\
\hline 15 & 0.11 & 0.53 \\
\hline 16 & 0.11 & 0.26 \\
\hline
\end{tabular}

For most of the samples the results determined through the Biochip method were close to those obtained through LC-MS/MS method. There were also some samples that produced different results, most likely because of the great complexity of honey sample composition, viscosity and sugar amount. But for screening purposes, the Biochip method proved to be a valuable monitoring instrument.

In terms of literature similar studies, there is more data that confirms the capacity and sensitivity of the Biochip method for identification of nitrofuran antibiotics in food [21, 22]. The limit of detection for the investigated Biochip technique was below $0.9 \mu \mathrm{g} / \mathrm{kg}$ for all metabolites, where the threshold limit was generally set at $1 \mu \mathrm{g} / \mathrm{kg}$. Therefore, our data is in accordance to other published studies that sustain the use of Biochip assay for the fast screening of banned antibiotic residues in different food samples. Moreover, the detection costs, speediness and reliability of this method represent more arguments for its use in food safety domain.

\section{Conclusions}

The Biochip technology allowed the quantification of residues of chloramphenicol in honey at levels that were lower than the minimum required performance limits. The sensitivity of the new quantitative determination method for chloramphenicol was high and it was evaluated as IC50 $(0.74 \mu \mathrm{g} / \mathrm{kg})$. The method presented very good accuracy both within the same analytical series and in different analytical series with typical values lower than $15 \%$ for concentration levels of $0.5,1$ and $1.5 \mu \mathrm{g} / \mathrm{kg}$. The decision limit $(\mathrm{CC} \alpha)$ of chloramphenicol was 0.37 $\mu \mathrm{g} / \mathrm{kg}$, while the detection capability $(\mathrm{CC} \beta)$ was $0.42 \mu \mathrm{g} / \mathrm{kg}$.

The validated Biochip method was applied to the analysis of 16 samples of honey from various geographic regions in Romania and the results were confirmed using a validated LC-MS/MS method. Although honey is considered a healthy natural product, the incidence of honey samples contaminated with traces of chloramphenicol was high.

\section{References}

1. Al-Waili N, Salom K, Al-Ghamdi A, Javed Ansari M, Antibiotic, Pesticide, and Microbial Contaminants of Honey: Human Health Hazards. Sci World J., 2012; 2012: 849-930.

2. Chen L, Li B, Magnetic molecularly imprinted poymer extraction of chloramphenicol from honey. Food Chem., 2013; 141: 23-28.

3. Eliakim-Raz N, Lador A, Leibovici-Weissman Y, Elbaz M, Paul M, Leibovici L, Efficacy and safety of chloramphenicol: joining the revival of old antibiotics? Systematic review and meta-analysis of randomized controlled trials. $J$ Antimicrob Chemother., 2015; 70(4): 979-996.

4. Findlay JWA, Dillard RF, Appropriate calibration curve fitting in ligand binding assays. AAPS J., 2007; 9(2): E260-E267.

5. Galarini R, Saluti G, Giusepponi D, Rossi R, Moretti S, Multiclass determination of 27 antibiotics in honey. Food Contr., 2015; 48: 12-24.

6. Grabek-Lejko D, Słowik J, Kasprzyk I, Activity of selected honey types against Staphylococcus aureus methicillin susceptible (MSSA) and methicillin resistant (MRSA) bacteria and its correlation with hydrogen peroxide, phenolic content and antioxidant capacity. Farmacia, 2018; 66(1): 37-43.

7. Hanekamp JC, Bast A. Antibiotics exposure and health risks: chloramphenicol. Environ Toxicol Pharmacol., 2015; 39(1): 213-220.

8. Jing $\mathrm{T}$, Gao XD, Wang $\mathrm{P}$, Wang $\mathrm{Y}$, Lin $\mathrm{YF}, \mathrm{Hu}$ XZ, Hao QL, Zhou YK, Mei SR, Determination of trace tetracycline antibiotics in foodstuffs by liquid chromatography-tandem mass spectrometry coupled with selective molecular-imprinted solidphase extraction. Anal Bioanal Chem., 2009; 393: 2009-2018. 
9. Joshi SR, Pechhacker H, Carbohydrate composition of nectar, honey and sugar candy of indian butter tree. Mellifera, 2002; 2(3): 57-60.

10. Khan SU, Anjum SI, Rahman K, Ansari MJ, Khan WU, Kamal S, Khattak B, Muhammad A, Khan HU, Honey: Single food stuff comprises many drugs. Saudi J Biol Sci., 2018; 25(2): 320-325.

11. Krivohlavek A, Žuntar I, Ivešić M, Andačić IM, Šikić S, Food safety is an important public health issue: Chloramphenicol residues determination by liquid chromatography tandem mass spectrometry (LC-MS/MS) in honey. Psychiatr Danub., 2014; 26(Supp13): 537-545.

12. Li J, Chen $\mathrm{H}$, Chen $\mathrm{H}$, Ye Y, Selective determination of trace thiamphenicol in milk and honey by molecularly imprinted polymer monolith microextraction and high-performance liquid chromatography. J Sep Sci., 2012; 35(1): 137-144.

13. Li XQ, Li HM, Xu S, Gao Y, Zhang QH, Zhang Y, Feng M, Rapid quantification of trace chloramphenicol in honey under ambient conditions using direct analysis via real-time QTRAP mass spectrometry. Food Chem., 2019; 276: 50-56.

14. Liu HY, Lin SL, Fuh MR, Determination of chloramphenicol, thiamphenicol and florfenicol in milk and honey using modified QuEChERS extraction coupled with polymeric monolith-based capillary liquid chromatography tandem mass spectrometry. Talanta, 2016; 150: 233-239.

15. Makovec S, Kos B, Šušković J, Bilandžić N, Tetracycline antibiotics and determination of their residues in food. Croat J Food Technol Biotechnol Nutr., 2014; 9: 7-16.

16. Malik AK, Blasco C, Picó Y, Liquid chromatography-mass spectrometry in food safety. J Chromatogr A, 2010; 1217(25): 4018-4040.

17. Matus E, Dunyach JJ, Albornoz A, Highly selective detection and identification of nitrofuran metabolites in honey using LC-MS/MS. Available at: http://thermo.com

18. Mitchell EAD, Mulhauser B, Mulot M, Mutabazi A, Glauser G, Aebi A, A worldwide survey of neonicotinoids in honey. Science, 2017; 358(6359): 109-111.

19. Morariu ID, Avasilcai L, Vieriu M, Panainte AD, Bibire N, Novel multiresidue method for the determination of eight trichothecene mycotoxins in pollen samples using QuEChERS-based GC-MS/ MS. Rev Chim (Bucharest), 2017; 68(2): 304-306.

20. Morariu ID, Avasilcai L, Vieriu M, Panainte AD, Bibire N, Validation and Application of an Analysis Method of Four Metabolites of Nitrofurans in Honey. Rev Chim (Bucharest), 2018; 69(10): 2808-2812.

21. Ohba $Y$, Nakajima T, Kanda M, Hayashi $H$, Matsushima Y, Nakagawa Y, Koike H, Nagano C, Simultaneous determination of nine acaricides and two metabolites in comb honey by LC/MS/MS. Food Addit Contam Part A Chem Anal Control Expo Risk Assess, 2018; 35(12): 2375-2386.

22. O'Mahony J, Moloney M, Mcconnell RI, Benchikh El O, Lowry P, Furey A, Danaher M, Simultaneous detection of four nitrofuran metabolites in honey using a multiplexing Biochip screening assay. Biosens Bioelectron, 2011; 26(10): 4076-4081.

23. Pongs O. Chapter 3: Chloramphenicol. In Hahn FE. Mechanism of action of antibacterial agents. Antibiotics Volume V Part 1. Berlin, Heidelberg: Springer Berlin Heidelberg, 1979, 26-42.

24. Popa (Morariu) ID, Schiriac EC, Matiut S, Cuciureanu R, Method validation for simultaneous determination of 12 sulfonamides in honey using Biochip array technology. Farmacia, 2012; 60(1): 143-154.

25. Popa ID, Schiriac EC, Cuciureanu R. Multianalytic detection of antibiotic residues in honey using a multiplexing Biochip assay. Med Chir J Rev., 2012; 116(1): 324-329

26. Popa Morariu ID, Schiriac EC, Ungureanu D, Cuciureanu $\mathrm{R}$, Immune response in rats following administration of honey with sulfonamides residues. Rev Romana Med Lab., 2012; 20(1): 63-72.

27. Rimkus GG, Hoffmann D, Enantioselective analysis of chloramphenicol residues in honey samples by chiral LC-MS/MS and results of a honey survey. Food Addit Contam Part A Chem Anal Control Expo Risk Assess, 2017; 34(6): 950-961.

28. Se KW, Ghoshal SK, Wahab RA, Ibrahim RKR, Lani MN, A simple approach for rapid detection and quantification of adulterants in stingless bees (Heterotrigona itama) honey. Food Res Int., 2018; 105: 453-460.

29. Śniegocki T, Gbylik-Sikorska M, Posyniak A, Analytical strategy for determination of chloramphenicol in different biological matrices by liquid chromatography - mass spectrometry. $J$ Vet Res., 2017; 61(3): 321-327.

30. Taka T, Baras MC, Chaudhry Bet ZF, Validation of a rapid and sensitive routine method for determination of chloramphenicol in honey by LCMS/MS. Food Addit Contam Part A Chem Anal Control Expo Risk Assess, 2012; 29(4): 596-601.

31. Van Der Heeft E, Bolck YJ, Beumer B, Nijrolder AW, Stolker AA, Full-scan accurate mass selectivity of ultra-performance liquid chromatography combined with time-of-flight and orbitrap mass spectrometry in hormone and veterinary drug residue analysis. $J$ Am Soc Mass Spectrom., 2009; 20(3): 451-463.

32. Verdon E, Couedor P, Sanders P, Multi-residue monitoring for the simultaneous determination of five nitrofurans (furazolidone, furaltadone, nitrofurazone, nitrofurantoine, nifursol) in poultry muscle tissue through the detection of their five major metabolites (AOZ, AMOZ, SEM, AHD, DNSAH) by liquid chromatography coupled to electrospray tandem mass spectrometry--in-house validation in line with Commission Decision 657/2002/EC. Anal Chim Acta, 2007; 586(1-2): 336-347.

33. Yang XF, Li NB, Luo HQ, Post-chemiluminescence determination of chloramphenicol based on luminolpotassium periodate system. Luminescence, 2012; 27(3): 217-222.

34. Yanovych D, Berendsen B, Zasadna Z, Rydchuk M, Czymai T, A study of the origin of chloramphenicol isomers in honey. Drug Test Anal., 2018; 10(3): 416-422. 